\title{
Batch and continuous of oil removal using organoclay and low-cost ceramic membrane
}

\author{
Remoção de óleo em batelada e fluxo contínuo utilizando argilla organofílica e membrana cerâmica \\ de baixo custo \\ Eliminación de aceite por lotes y de flujo continuo utilizando arcilla organofílica y membrana \\ cerámica de bajo costo
}

Recebido: 29/10/2021 | Revisado: 06/11/2021 | Aceito: 15/11/2021 | Publicado: 25/11/2021

\author{
Ana Beatriz de França Silva Araújo \\ ORCID: https://orcid.org/0000-0002-6368-3385 \\ Universidade Federal de Campina Grande, Brasil \\ E-mail: biafranca1005@gmail.com \\ Edilânia Silva do Carmo \\ ORCID: https://orcid.org/0000-0002-5095-7279 \\ Universidade Federal de Campina Grande, Brasil \\ E-mail: edilania.carmo@eq.ufcg.edu.br \\ Rochelia Silva Souza Cunha \\ ORCID: https://orcid.org/0000-0001-9305-5104 \\ Universidade Federal de Campina Grande, Brasil \\ E-mail: rocheliachel@hotmail.com \\ Francisco Alex de Sousa Silva \\ ORCID: https://orcid.org/0000-0002-3580-6966 \\ Universidade Federal de Campina Grande, Brasil \\ E-mail: francisco.sousa@eq.ufcg.edu.br \\ Tellys Lins Almeida Barbosa \\ ORCID: https://orcid.org/0000-0002-3733-4333 \\ Universidade Federal de Campina Grande, Brasil \\ E-mail: tellyslins@hotmail.com \\ Meiry Gláucia Freire Rodrigues \\ ORCID: https://orcid.org/0000-0003-2258-4230 \\ Federal University of Campina Grande, Brazil \\ E-mail: meiry.rodrigues@ufcg.edu.br
}

\begin{abstract}
The objective of this work was to compare two oily effluent treatment systems, batch process and membrane separation process (PSM). In the batch process an organophilic clay was used and in the PSM a low cost ceramic membrane was used. A bofe clay was used as raw material for the preparation of organophilic clay prepared with surfactant, via direct method and characterized by X-ray diffraction. The sorption properties of this organoclay were evaluated to remove oil. The low-cost, disc-shaped ceramic membrane was obtained from natural bofe clay from BoaVista, Paraíba, Brazil. The uniaxial dry compaction method and sintering at $650{ }^{\circ} \mathrm{C}$ was used. The membrane was characterized by XRD and water permeability and its performance was evaluated by oil/water emulsion separation tests from a synthetic effluent, using a stainless steel module under the conditions of initial concentration of the emulsion $125 \mathrm{mg} . \mathrm{L}^{-1}$, temperature of $25^{\circ} \mathrm{C}$ and pressure of 2.0 bar. It is concluded that the two processes (PSM and batch system using bofe organophilic clay as adsorbent) can be used and are promising for the treatment of oily water. Keywords: Low-cost membrane; Ceramic membrane; Batch adsorption; Oily wastewater; Oil rejection.
\end{abstract}

\section{Resumo}

O objetivo deste trabalho foi comparar dois sistemas de tratamento de efluentes oleosos, processo em batelada e processo de separação por membrana (PSM). No processo em batelada foi utilizada uma argila organofílica e no PSM foi utilizada uma membrana cerâmica de baixo custo. Uma argila de bofe foi utilizada como matéria-prima para a preparação de argila organofílica preparada com surfactante, via método direto e caracterizada por difração de raios$\mathrm{X}$. As propriedades de sorção desta organofílica foram avaliadas para remover o óleo. A membrana cerâmica de baixo custo em forma de disco foi obtida a partir de argila de bofe natural de Boa-Vista, Paraíba, Brasil. Foi utilizado o método de compactação uniaxial a seco e sinterização a $650^{\circ} \mathrm{C}$. A membrana foi caracterizada por DRX e permeabilidade à água e seu desempenho foi avaliado por testes de separação emulsão óleo/água de um efluente sintético, utilizando um módulo de aço inoxidável nas condições de concentração inicial da emulsão 125 mg.L ${ }^{-1}$, 
temperatura de $25{ }^{\circ} \mathrm{C}$ e pressão de 2,0 bar. Conclui-se que os dois processos (PSM e sistema batelada utilizando argila organofílica bofe como adsorvente) podem ser utilizados e são promissores para o tratamento de água oleosa.

Palavras-chave: Membrana de baixo custo; Membrana cerâmica; Adsorção em batelada; Águas residuais oleosas; Rejeição de óleo.

\section{Resumen}

El objetivo de este trabajo fue comparar dos sistemas de tratamiento de efluentes oleosos, el proceso por lotes y el proceso de separación por membrana (PSM). En el proceso discontinuo se utilizó una arcilla organofílica y en el PSM se utilizó una membrana cerámica de bajo costo. Se utilizó una arcilla bofe como materia prima para la preparación de arcilla organofílica preparada con surfactante, vía método directo y caracterizada por difracción de rayos X. Se evaluaron las propiedades de sorción de este organófilo para eliminar el aceite. La membrana cerámica en forma de disco de bajo costo se obtuvo de arcilla bofe natural de Boa-Vista, Paraíba, Brasil. Se utilizó el método de compactación seca uniaxial y sinterización a $650^{\circ} \mathrm{C}$. La membrana se caracterizó por XRD y permeabilidad al agua y su desempeño se evaluó mediante pruebas de separación de emulsión aceite / agua de un efluente sintético, utilizando un módulo de acero inoxidable en las condiciones de concentración de la emulsión $125 \mathrm{mg} . \mathrm{L}-1$, temperatura de $25^{\circ} \mathrm{C}$ y presión de 2,0 bar. Se concluye que los dos procesos (PSM y sistema discontinuo que utiliza arcilla organofílica bofe como adsorbente) pueden utilizarse y son prometedores para el tratamiento de aguas aceitosas.

Palabras clave: Membrana de bajo costo; Membrana de cerámica; Adsorción por lotes; Aguas residuales aceitosas; Rechazo de aceite.

\section{Introduction}

Oily water emulsions are the main pollutants emitted into water by industry and domestic sewage and are the major pollution problem because oilfield produced water has distinctive characteristics due to organic and inorganic matter. Mainly, it includes salt and hydrocarbons, which may be toxic to the environment (Tummons et al., 2020; Alzahrani, \& Mohammad, 2014; Ebrahimi et al., 2017). So far, there are several techniques for oil separation. Typical ones include chemical emulsification, $\mathrm{pH}$ adjustment, gravity settling, centrifugal settling, filter coalesce, heating treatment, electrostatic coalesce, membrane filtration, etc. There are some advantages and disadvantages for each of these techniques (Tummons et al., 2020; Alzahrani, \& Mohammad, 2014).

Several common techniques are used in oil-water separation and treatment (Gupta et al., 2017; Matsuno et al., 2021). The gravity settling separation (Le et al., 2013) and mechanical coalescence methods (Hazlett, 1969; Sutherl, 2008) are the well-known traditional treatment processes, the efficiency of which depends on the size of the oil droplets in wastewater (Abuhasel et al., 2021)

Membrane separations have been developed greatly over the last 30 years and are becoming a promising technology (Hsieh, 1996; Burggraaf, \& Cot, 1996; Cot et al., 2000). They are used in industrial processes and are utilized currently for oilfield produced water treatment. They have high oil removal efficiency, low energy cost and compact design compared with traditional treatment methods. This technology has several advantages including stable effluent quality and small area requirement. Moreover, no chemical addition is required (Padaki et al., 2015; Zhu et al., 2014).

There has been important progress in the use of low-cost raw materials as precursors to ceramic membranes. (Mestre et al., 2019; Nandi, Uppaluri, \& Purkait, 2008; Monash, \& Pugazhenthi, 2011; Kaur et al., 2016; He et al., 2019; Ghouil et al., 2016).

This work is part of a line of research developed at the Laboratory of Development of New Materials-LABNOV of the UFCG. This line of research covered a series of studies on the synthesis of inorganic membranes in the oil/water emulsion separation process (Barbosa, 2009; Araújo, 2010; Araújo et al., 2010; Queiroz et al., 2010; Araújo et al., 2012; Barbosa, 2013; Santos, 2014; Santos et al., 2014; Santos et al., 2014; Santos et al., 2015; Araújo, 2014; Barbosa, 2015; Barbosa et al., 2015; Scheibler, 2015; Scheibler et al, 2015; Silva et al., 2015; Cunha, 2017; Mota, 2017; Silva et al., 2017; Barbosa et al., 2018; Barbosa et al., 2019; Silva et al., 2021; Silva et al., 2021; Barbosa et al., 2021).

The choice of this support was based on two major reasons: first, the bofe is environmentally friendly, abundant and 
low-cost material. In addition, the State of Paraíba has the largest Brazilian reserves of smectitic clays. Second, the support is energy-saving (the sintering temperature is equal to $650{ }^{\circ} \mathrm{C}$ ). Therefore, the aim of this study was to compare the two oily effluent treatment systems, batch process and membrane separation process (PSM). In the batch system an organoclay was used and in the membrane separation system a low cost membrane was used.

\section{Methodology}

This work was carried out at the Laboratório de Desenvolvimento de Novos Materiais (LABNOV), belonging to the Unidade Acadêmica de Engenharia Química, located at the Centro de Ciências e Tecnologia of the Universidade Federal de Campina Grande (UAEQ/CCT/UFCG).

\subsection{Materials and Chemical}

Bofe clay is found in abundance in the state of Paraíba and was made available by Bentonit União Nordeste (BUN), located in the city of Campina Grande, Paraíba. Food grade starch was bought at a local market.

The reagents used were, the mineral lubricating oil used is LJ SAE 40 Lubrax, supplied by Petrobras, Chloroform P.A. (CHCl3) 99.9 Dynamics and distilled water.

The equipment used was an analytical balance Mars - Al 200 C, mechanical stirrer for dispersion MA 147 Marconi, Muffle Quimis Q318M, shaking table (Braun Certomat MO, Biotech International), Brookfield DV-II Pro viscometer (rotational), Anton Paar digital density meter, model 30px, universal testing machine (Instron 1000 KN EMIC), Cole Palmer Masterflex L/S peristaltic pump, UV-Spectrophotometer 1600 Pro-Analysis.

\subsection{Methods}

\subsubsection{Preparation of organoclay}

The organoclay synthesis was performed by a procedure involving the cation exchange reaction based on the "direct method" according to the procedure described by authors (Pereira et al., 2005; Mota et al., 2012; Mota, Rodrigues \& Machado, 2014). Initially, a clay dispersion (4 wt\%) was prepared in distilled water and treated with a solution of sodium carbonate, with stirring (600 rpm for 20 minutes) at $95{ }^{\circ} \mathrm{C}$. After sedimentation of the sample, $20.4 \mathrm{~g}$ of quaternary ammonium salt (CTAC) was added and stirred for $30 \mathrm{~min}$. The sample was then filtered and washed successively with $4 \mathrm{~L}$ of distilled water. The solid pellets were filtered, dried at $60 \pm 5^{\circ} \mathrm{C}$ for 24 hours and and sieved in a Tyler 200 Mesh (sieve opening equal to $0.074 \mathrm{~mm}$ ).

\subsubsection{Preparation of low-cost ceramic membranes}

The method used is based on the work of authors (Vasanth, Uppaluri \& Pugazhenthi, 2011). Low-cost ceramic membranes were prepared using bofe clay and starch by the uniaxial dry compaction methodology. Raw material was dried in stove at $100{ }^{\circ} \mathrm{C}$ for $24 \mathrm{~h}$. Dried material was crushed in ball mill at $170 \mathrm{rpm}$ for $2 \mathrm{~h} .90 \%$ of bofe clay was mixed with $10 \%$ of starch and then sieved using a mesh strainer \#200 with a sieve opening of $0.074 \mathrm{~mm}$. Homogenized powder was introduced into stainless steel mould (flat cylindrical) with diameter of $22 \mathrm{~mm}$ and thickness of $4 \mathrm{~mm}$. The shaping of flat disks was fabricated by hydraulic uniaxial pressing method. Flat membrane with $2 \mathrm{~mm}$ in thickness was shaped by applying uniaxial pressure of 5 tones during 2 min.

The membranes were sintered at $650{ }^{\circ} \mathrm{C}$ in a programmable furnace according to thermal program: a relatively slow temperature increasing rate $\left(5^{\circ} \mathrm{C} \cdot \mathrm{min}^{-1}\right)$ was needed in order to avoid the formation of craks, for 2 hours. Cooling of the furnace from sintering temperature to room temperature was carried out by simple automatic heating shutdown. 


\subsection{Characterization}

\subsubsection{Cation exchange capacity (CEC)}

The cation exchange capacity (CEC) was determined using the Kjeldahl method with a Kjeldahl distiller, (Marconi model MA-036Plus, São Paulo).

\subsubsection{X-ray Diffraction (XRD)}

X-ray diffraction analysis of samples was performed using a diffractometer Shimadzu XRD 6000m, Kyoto, Japan with Copper $\mathrm{K} \alpha$ radiation, operated at $30 \mathrm{~mA}$ and $40 \mathrm{KV}$, with a goniometer velocity of $2 \% \mathrm{~min}$ and a step of $0.02{ }^{\circ}$ in the range of $2 \theta$ scanning from $2^{\circ}$ to $50^{\circ}$.

\subsubsection{Adsorption Capacity}

The gasoline, diesel, kerosene and lubricating oil sorption capacity was measured following a method based on the "Standard Methods of Testing Sorbent Performance of Adsorbents (ASTM F716-82 and ASTM F 726-99)".

\subsubsection{Mechanical strength}

The low-cost ceramic membrane mechanical properties were determined by the diametral compression traction following the technical norm ASTM C158 in a universal test machine. A diametral compression test was used to evaluate the tensile strength of the low-cost ceramic membrane. A sample dimension of $22 \mathrm{~mm}$ x $4 \mathrm{~mm}$ (diameter x thickness) was used to ensure that the samples were tested under plane stress conditions.

From the results obtained in the characterization, it is also possible to calculate the pore radius of the membrane. The equation used is the Guerout-Elford-Ferry equation:

$$
\begin{gathered}
r=\sqrt{\frac{(2,9-1,75 \varepsilon) 8 \eta h Q}{\varepsilon A \Delta P t}} \\
\mathrm{~J}=\frac{\mathrm{Q}}{\mathrm{At}} \\
r=\sqrt{\frac{(2,9-1,75 \varepsilon) 8 \eta h}{\varepsilon \Delta P} * J}
\end{gathered}
$$

Where $\varepsilon$ expresses porosity, $\eta$ is the viscosity of water under ambient conditions and is given in (Pa.s), oh is the membrane thickness in meters, $\Delta \mathrm{P}$ is the pressure variation at the time the flow of pure water was performed. in $(\mathrm{Pa})$ and $\mathrm{J}$ indicates the average flow for that pressure $\left(\mathrm{m}^{3} \cdot \mathrm{s}^{-1} \cdot \mathrm{m}^{-2}\right)$.

\subsubsection{Porosity}

Porosity was determined according to the ASTM C 20 (2000). The determination of apparent porosity was determined by the immersion method, which is based on the principle of Archimedes, using water as a fluid, according to ASTM C 20 
(2000). The determination was carried out with the aid of a analytical balance. The test was carried out using replicas for each formulation. After obtaining the dry, immersed and wet mass of the ceramic bodies, it was possible to calculate the apparent porosity using Equation 4.

$$
\mathrm{P}=\frac{\mathrm{Mu}-\mathrm{Ms}}{\mathrm{Mu}-\mathrm{Mi}}(100)
$$

Where Mu is the wet mass; Ms is the dry mass; Mi is the immersed mass.

\subsection{Batch adsorption}

Oil removal and capacity were determined from batch adsorption according to literature (Tien, 1994). The mineral oil was dissolved in deionised water to prepare emulsion oil water with initial concentration $100 \mathrm{mg} . \mathrm{L}^{-1}$. The solution (volume of $50 \mathrm{~mL}$ ) was put in contact with $0.5 \mathrm{~g}$ of clay organophilic clay in erlenmeyer flasks and $\mathrm{pH}$ of 6 . The contents were mixed on a shaking table at $200 \mathrm{rpm}\left(25^{\circ} \mathrm{C}\right)$ for $6 \mathrm{~h}$, in order to guarantee the equilibrium of the system (Mota, Rodrigues \& Machado, 2014).

The total oil removal percentage (\%Rem) and the capacity of oil removal at equilibrium (qeq, in $\mathrm{mg}$ of oil/g of adsorbent) were obtained with Equations 5 and 6, respectively:

$$
\begin{gathered}
\% \text { Rem }=\left(\frac{\mathrm{C}_{0}-\mathrm{C}_{\mathrm{eq}}}{\mathrm{C}_{0}}\right) * 100 \\
\mathrm{q}_{\text {eq }}=\frac{\mathrm{V}}{\mathrm{m}}\left(\mathrm{C}_{\mathrm{o}}-\mathrm{C}_{\mathrm{eq}}\right)
\end{gathered}
$$

Where, \% Rem is the removal percentage; $\mathrm{q}_{\mathrm{eq}}$ is the removal capacity (mg of oil/g of adsorbent); $\mathrm{V}$ is the volume of oil solution $(\mathrm{L})$; $\mathrm{m}$ is the mass of adsorbent $(\mathrm{g}) ; \mathrm{C}_{0}$ is the initial concentration of dye solution $\left(\mathrm{mg} . \mathrm{L}^{-1}\right)$; and $\mathrm{C}_{\mathrm{eq}}$ is the final concentration remaining after the batch process $\left(\mathrm{mg} \cdot \mathrm{L}^{-1}\right)$.

\subsection{Water flux measurements}

Test was determined using homemade plant. A flat sheet membrane module made of stainless steel was used in the experiment. The effective area of the membrane in the module was $0.22 \mathrm{~m}^{2}$. Experiments were carried out at a pressure of 2.0 bar, at $25^{\circ} \mathrm{C}$, during $120 \mathrm{~min}$, and the flux was calculated by Equation 7:

$$
\mathrm{J}=\mathrm{V} / \mathrm{A} * \mathrm{t}(\mathrm{c})
$$

Where $\mathrm{J}$ is the water flux $\left(\mathrm{L} \cdot \mathrm{m}^{-2} \cdot \mathrm{h}^{-1}\right), \mathrm{V}$ is the permeate volume $(\mathrm{L}), \mathrm{A}$ is the membrane effective area $\left(\mathrm{m}^{2}\right)$ and $\mathrm{t}$ is the permeation time $(\mathrm{h})$.

\subsection{Separation of emulsion oil water}

Test was performed using homemade plant at a temperature of $25{ }^{\circ} \mathrm{C}$ and pressure of 2.0 bar. The permeate flux was calculated, using equation 1 , by dividing the permeate volume by the product of the membrane area and the sampling time. The system used in the oil water separation process measurements has the components: lotion (L); peristaltic pump with a flowrate 
of $0.002 \mathrm{~L} . \mathrm{min}^{-1}$; ceramic membrane permeation module. The permeate samples were run at 20 min intervals for a total period of $120 \mathrm{~min}$ for membrane.

In addition, the main properties of oil are summarized in Table 1.

Table 1. Properties of lubricant oil selected for this present study.

\begin{tabular}{ccc}
\hline Characteristics & Method & Specification \\
\hline Appearance $@ 30{ }^{\circ} \mathrm{C}$ & Visual & Clear liquid \\
\hline Density@ $29.5^{\circ} \mathrm{C}, \mathrm{mg} . \mathrm{L}^{-1}$ & IS $1115-86$ P: 32 & 0.8833 \\
\hline Dinamic viscosity $@ 40^{\circ} \mathrm{C}, \mathrm{cSt}$. & IS $1115-86$ P: 25 & 168 \\
\hline
\end{tabular}

Source: Authors.

Density: The density of the sample was determined at $29.5^{\circ} \mathrm{C}$ with a digital densitometer, model 30px. A 2-mL aliquot of lubricaiting oil was added to the densimeter and the result was recorded.

Viscosity: Viscosity measurements were carried out with lubricating oil by using the Brookfield DV-II Pro(rotational) viscometer.

\subsubsection{Effluents characterization}

The same system used in the water flux measurements, previously shown was employed for the separation of emulsion oil/water. Oily wastewater was prepared emulsifying $0.05 \mathrm{~g}$ of lubricant oil in $500 \mathrm{~mL}$ of distilled water under stirring (highspeed stirrer $17.000 \mathrm{rpm}$ ) for 20 min to produce stable emulsion. The membrane filtration was carried out at a pressure of 2.0 bar. The oil concentrations of the feed and permeate streams were analyzed. The oil concentration was measured by an UVvisible spectrophotometer.

The permeate flux was calculated by dividing the permeate volume by the product of the membrane area and the sampling time. The oil retention coefficient $\mathrm{R}$ was calculated as a percentage according to Equation 8 :

$$
\% R=\left(\frac{C_{f}-C_{p}}{C_{f}}\right) * 100
$$

where $C_{f}$ is the oil concentration in the feed, and $C_{p}$ is the oil concentration in the permeate. Flow membrane operation was used in the filtration experiments.

\section{Results and Discussion}

\subsection{Bofe clay}

Table 2 shows some properties of the bofe clay. The value obtained from the cation exchange capacity for bofe clay (71.00 meq/100g of bofe clay) is in line with the expected range for smectite clays from Paraíba. According to the literature, the smectite group in Paraíba has values in the range of 50 to $90 \mathrm{meq} / 100 \mathrm{~g}$ of clay (Souza-Santos, 1989). The lower CEC values indicate that the clay minerals have a high amount of impurities or a low level of isomorphic substitutions. According to, the data in Table 2 was observed that the bofe clay obtained a better performance in kerosene and diesel solvent (1.10 and $1.40 \mathrm{mg} . \mathrm{g}^{-1}$ ) when compared with the solvent gasoline. Similar behavior was found in the literature for green clay (Mota et al., 2011). 
Table 2. Cation exchange capacity and adsorption capacities results in different organic solvents.

\begin{tabular}{cccccc}
\hline Organoclay & CEC $(\mathbf{m e q} / \mathbf{1 0 0} \mathbf{g})$ & $\mathbf{G}\left(\mathbf{m g . g}^{\mathbf{- 1}}\right)$ & $\mathbf{K}\left(\mathbf{m g . g} \mathbf{- 1}^{\mathbf{1}}\right)$ & $\mathbf{D}\left(\mathbf{m g . g}^{\mathbf{- 1}}\right)$ & Ref. \\
\hline Bofe & 71.00 & 0.80 & 1.10 & 1.40 & This work \\
\hline Green & 73.00 & 0.92 & 1.98 & 1.95 & Mota et al., 2011 \\
\hline
\end{tabular}

*G: Gasoline; K: Kerosene; D: Diesel. Source: Authors.

Figure 1 presents the X-ray patterns of bofe clay and organoclay. Qualitatively clay mineral smectite bofe presents as it is also observed the presence of quartz. Results consistent with those found in literature (Rodigues, 2003; Oliveira et al., 2012).

Figure 1. X-ray patterns of clay and organoclay.

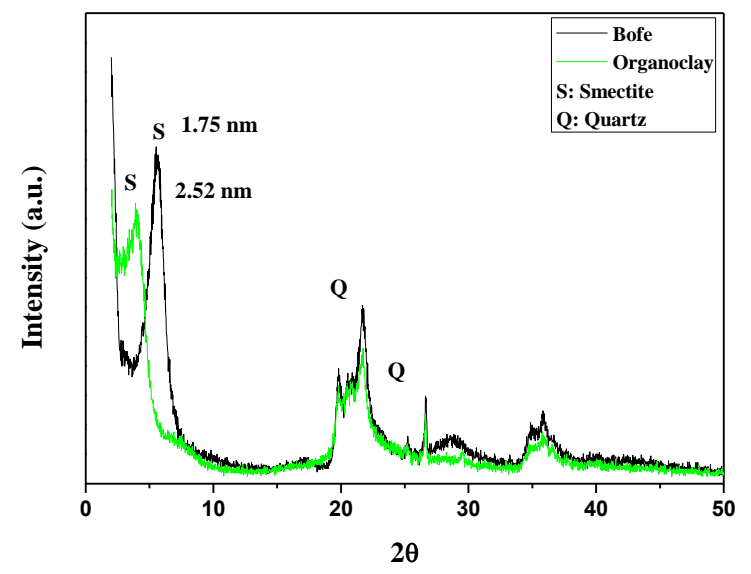

Source: Authors.

It can be seen that after treatment the bofe clay with the surfactant, changes in the basal spacing was compared with that of bofe clay. This change can be attributed to the difference in spacing. The bofe clay has a basal spacing of $1.75 \mathrm{~nm}$ and organoclay shows a spacing of $2.52 \mathrm{~nm}$, verifying an increase of $0.77 \mathrm{~nm}$. It is also observed other peaks that are not related to smectite mineral like quartz that has as an impurity (Xi et al., 2010). This significant increase in $\mathrm{d}_{(001)}$ of organoclay shows the effective incorporation of surfactant in the interlayer of the clay layers. This expansion of the clay layer was also found in the literature regardless of the salt used (Bergaya, 2006; Rodrigues et al., 2010; Mota el al., 2011; Silva et al., 2014).

The results obtained for the percentage of oil removal and the removal capacity are presented in Table 3 . This study was carried out for the system used to remove lubricating oil from synthetic effluents with organoclay.

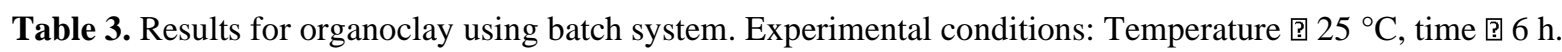

\begin{tabular}{|c|c|c|c|c|c|}
\hline Solvent & $\begin{array}{c}\mathrm{C}_{0} \\
\operatorname{calc} /\left(\mathrm{mg} . \mathrm{L}^{-1}\right)\end{array}$ & $\mathbf{A}(\mathbf{r p m})$ & Oil /(mg.L $\left.\mathbf{L}^{-1}\right)$ & $\%$ Rem & qeq $\left(\mathrm{mg} \mathrm{g}^{-1}\right)$ \\
\hline Gasoline & 302 & 200 & 3.40 & 98.87 & 29.86 \\
\hline Diesel & 316 & 200 & 4.61 & 97.37 & 30.77 \\
\hline Lubricating oil & 300 & 200 & 10.69 & 96.55 & 29.93 \\
\hline
\end{tabular}


Where: $\mathrm{C}_{0}$ calc - theoretical initial concentration; $\mathrm{A}$ - mechanical agitation; \%Rem - total oil removal percentage; qeq - removal capacity oil at equilibrium.

In these assays, organoclay was allowed to interact with different organic solvents (gasoline, diesel and lubricating oil). The results of total oil removal percentage and removal capacity oil at equilibrium were very similar regardless of the solvent used (gasoline, diesel and lubricating oil), despite the different characteristics, carbon chain length, viscosity, densities, under the temperature conditions used in this study.

Similar results were found in the study carried out by the authors (Mota, Rodrigues \& Machado, 2014). An green organoclay was used under the study conditions of $300 \mathrm{mg} \cdot \mathrm{L}^{-1}$ and $100 \mathrm{rpm}$ of agitation, found $91.54 \%$ of total lubricating oil removal percentage and $33.69 \mathrm{mg} . \mathrm{L}^{-1}$ of capacity of oil removal at equilibrium.

\subsection{Low-cost ceramic membrane}

XRD diffractogram of low-cost ceramic membrane (sintered at $650{ }^{\circ} \mathrm{C}$ ) is presented in Figure 2.

Figure 2. Diffractogram of the low-cost ceramic membrane (sintered at $650{ }^{\circ} \mathrm{C}$ ).

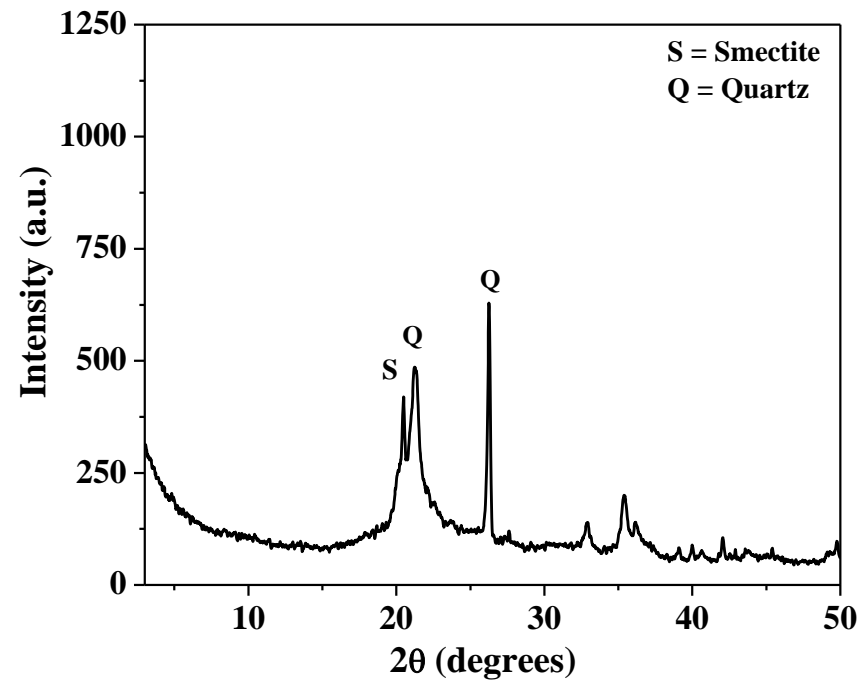

Source: Authors.

As presented in Figure 2, the peak equivalent to the clay mineral smectite is destroyed. This result indicates a partial breakdown of the crystalline structure (Rezende \& Pinto, 2016). In soil science, the swelling and collapsing behavior resulting from the hydration and dehydration process is the underlying mechanism of numerous problems. This behavior is related to the shrinkage effect, which can generate additional preferential pathways for water/contaminant transfer (Ferrage, 2016). Normally, there are three forms of water in smectite interlayers, including adsorbed water, hydrate water, and constitution water (Mercurio et al., 2016).

The results of porosity and mechanical strength of the low-cost ceramic membrane are presented in Table 4. The results of tensile strength of the low-cost ceramic membrane was 2 bar and it was sintered at a temperature of $650{ }^{\circ} \mathrm{C}$ and porosity of $48.16 \%$. A comparison between porosity and mechanical strength parameters in this present work and those reported in the literature (Table 3) shows that, the effect of starch addition or any other porosity agent on the properties of ceramic membranes is generally linked to the sintering temperature. Provided that a minimum amount of starch is added to the membrane composition (around $5 \%$ ) the starch content practically determines the value of water permeability of the ceramic membrane since the pores generated by the starch become interconnected and therefore accessible to fluids (Lorente-Ayza et al., 2015). 
Strength of the ceramic membrane depends on the presence of the defects, such as pores, which act as stress concentration (Chandradass et al., 2009). The flexural strength is proportional with the apparent porosity of the ceramic membrane.

The shrinkage might be ocurred due to the losses of moisture and burn out of the corn starch during sintering process. The density of the membrane is decreased as the corn starch content is increase. The decrease in density value is caused by the formation of pore by corn starch removing. A similar finding was also obtained by other authors using different starch content by various preparation process of porous structure (Yang \& Tsai, 2008; Barbosa et al., 2018; Barbosa et al., 2019; Hsieh, 1996; Lorente-Ayza et al., 2015).

Table 4. Comparison between porosity and mechanical strength values of ceramic membrane prepared in this work and those reported in the literature.

\begin{tabular}{|c|c|c|c|c|c|}
\hline Membrane & $\begin{array}{l}\mathbf{T}_{\text {sint }} \\
\text { (回C) }\end{array}$ & $\begin{array}{c}\text { pore diameter } \\
(\mu \mathrm{m})\end{array}$ & $\begin{array}{c}\text { Porosity } \\
(\%)\end{array}$ & $\begin{array}{c}\text { Mechanical strength } \\
\text { (MPa) }\end{array}$ & Ref. \\
\hline $\begin{array}{c}\text { Bofe Clay }+ \text { corn starch } \\
\qquad(10 \%)\end{array}$ & 650 & 0.2011 & 48.16 & - & Present work \\
\hline $\begin{array}{c}\text { Brasgel Clay + corn } \\
\operatorname{starch}(1 \%)\end{array}$ & 650 & 0.4559 & 18.79 & 8.2 & Silva et al., 2021 \\
\hline $\begin{array}{c}\text { Clay }+ \text { corn starch } \\
(10 \%)\end{array}$ & 950 & - & 35.80 & 14.0 & $\begin{array}{l}\text { Barredo-Damas et al., } \\
\qquad 2010\end{array}$ \\
\hline alpha-alumina & 1200 & - & 33.37 & 9.4 & Almeida et al., 2009 \\
\hline
\end{tabular}

Source: Authors.

\subsection{Water flux measurements}

Pure water permeation experiments are one of the most crucial methods for finding the structure and morphology of membranes. Pure water flux is affected by the membrane structure (porosity) and subsequently by preparation variables (Hsieh, 1996). The water flux through the ceramic membrane was evaluated using pure distilled water as a permeate.

As seen in the Figure 3, the flux of pure water remained essentially constant all the time the 120 min. This behavior showed that the pure water flux of the low cost membrane was influenced for the most part by the porosity and pore size distribution.

The authors (Barbosa, Barbosa \& Rodrigues, 2019) studied the ceramic membrane prepared from alumina by uniaxial dry compaction method under the same conditions as this work (Experimental conditions: under pressure 2.0 bar, during 60 min and temperature at $25^{\circ} \mathrm{C}$ ) and the result found for pure water flow was greater than $1000 \mathrm{~L} \cdot \mathrm{m}^{-2} \cdot \mathrm{h}^{-1}$. 
Figure 3. Pure water flux measurements. Experimental conditions were $2.0 \mathrm{bar}, 25^{\circ} \mathrm{C}$, running time $=120 \mathrm{~min}$.

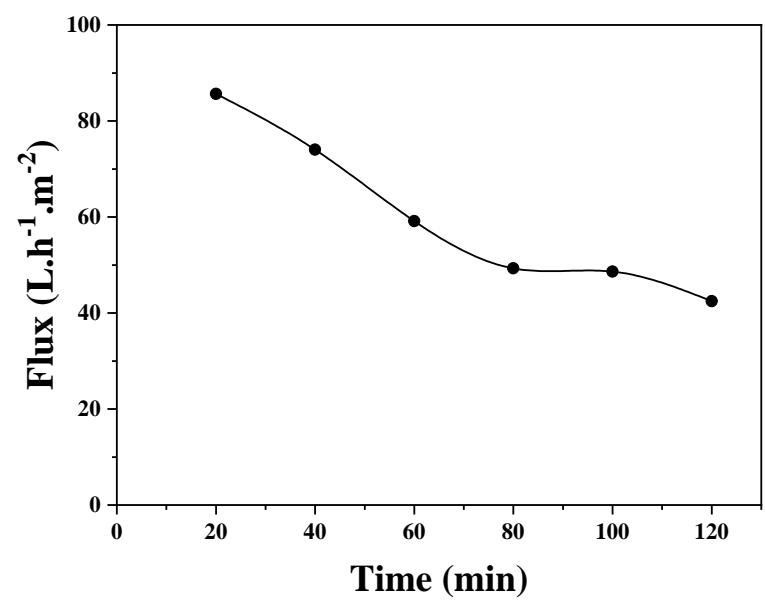

Source: Authors.

We compared the pure water flux of two different ceramic membranes (clay and alumina), studied under the same conditions. Pure water flux showed that the PWF of alumina membrane was greather than to PWF of low-cost ceramic membrane. The difference can probably be attributed to characteristics of each membrane (clay and alumina), such as porosity, pore diameter, hydrophilicity.

\subsection{Separation of oil/water emulsion}

The effect of filtration time on flow and rejection was studied. Figure 4 represents flow and rejection versus filtration time under 2.0 bar pressure using a feed with an oil-water emulsion concentration of $125 \mathrm{mg} . \mathrm{L}^{-1}$.

Figure 4. Removal of oil-water emulsion as a function of time for the low-cost membrane. Experimental conditions were 2.0 bar, $25^{\circ} \mathrm{C}$, running time $=120 \mathrm{~min}, \mathrm{pH}$ oil-water emulsion $=6$.

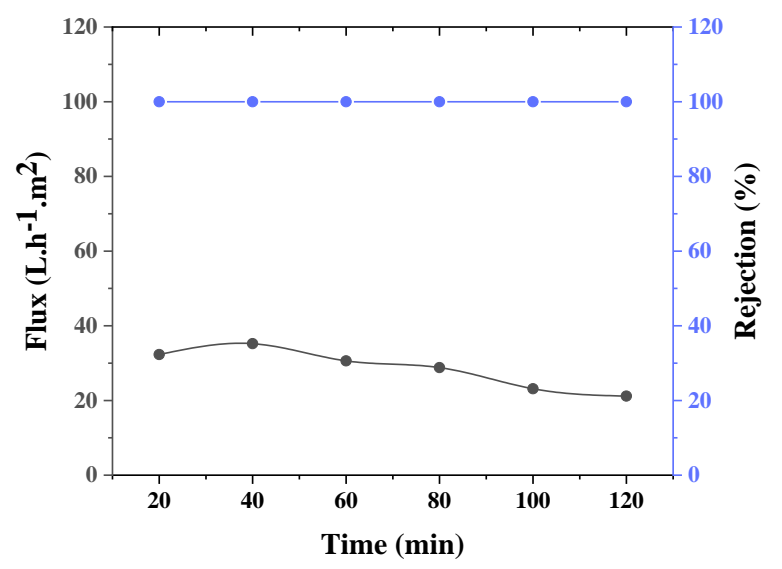

Source: Authors.

From the data, presented in Figure 4, it is possible observe a slight reduction in flux through the low cost membrane over time. This shows that the oil/water emulsion flow through the membrane shrinks over time. The results of the experiment using membrane low-cost show that after $120 \mathrm{~min}$ there is no change in rejection, and this remained stable and satisfactory 
over the time interval, as shown in Figure 4. Based on the oil separation test, the low-cost membrane was efficient, removing up to $100.00 \%$ of the oil.

Results of the performance of other inorganic microfiltration membranes used for the oil-water emulsion separation results are shown in Table 5. In comparison with the results found in the literature, the ceramic membrane results produced in this work were satisfactory.

Table 5. Membranes of microfiltration inorganic used for the oil-water emulsion separation results.

\begin{tabular}{|c|c|c|c|c|c|c|}
\hline Membrane & $\begin{array}{l}\text { Method of } \\
\text { preparation }\end{array}$ & $\begin{array}{l}\text { Operational } \\
\text { parameters }\end{array}$ & Parameters & $\underset{\left(\mathbf{L} \cdot \mathbf{m}^{-2} \cdot \mathbf{h}^{-1}\right)}{\text { Flux }}$ & $\begin{array}{c}\text { Rejection } \\
\text { efficiency } \\
(\%) \\
\end{array}$ & Ref. \\
\hline $\begin{array}{l}\text { Low-cost } \\
\text { ceramic }\end{array}$ & $\begin{array}{l}\text { uniaxial dry } \\
\text { compaction }\end{array}$ & $\begin{array}{c}2.0 \mathrm{bar} \\
25^{\circ} \mathrm{C}\end{array}$ & $\begin{array}{c}\text { lubricating oil } \\
\text { wastewater }\end{array}$ & 28.54 & 100.00 & This work \\
\hline Composite & $\begin{array}{l}\text { mechanical } \\
\text { mixture }\end{array}$ & $\begin{array}{c}2.0 \mathrm{bar} \\
25^{\circ} \mathrm{C}\end{array}$ & $\begin{array}{l}\text { lubricating oil } \\
\text { wastewater } \\
\mathrm{C}_{\mathrm{f}}=100 \mathrm{mg} . \mathrm{L}^{-1} \\
\mathrm{C}_{\mathrm{p}}=2.2 \mathrm{mg} . \mathrm{L}^{-1}\end{array}$ & 150.00 & 97.80 & $\begin{array}{c}\text { Barbosa et } \\
\text { al., } 2020\end{array}$ \\
\hline Composite & $\begin{array}{c}\text { mechanical } \\
\text { mixture }\end{array}$ & $\begin{array}{c}\mathrm{P} \text { atmospheric } \\
25^{\circ} \mathrm{C}\end{array}$ & $\begin{array}{c}\text { lubricating oil } \\
\text { wastewater } \\
\mathrm{C}_{\mathrm{f}}=600 \mathrm{mg} . \mathrm{L}^{-1}\end{array}$ & 264.00 & 91.33 & $\begin{array}{l}\text { Scheibler } \\
\text { et al., } 2014\end{array}$ \\
\hline $\begin{array}{c}\mathrm{NaA} / \alpha- \\
\mathrm{Al}_{2} \mathrm{O}_{3}\end{array}$ & $\begin{array}{c}\text { Hidrothermal } \\
100^{\circ} \mathrm{C} 4 \mathrm{~h}\end{array}$ & $\begin{array}{c}2.0 \mathrm{bar} \\
25^{\circ} \mathrm{C}\end{array}$ & $\begin{array}{l}\text { lubricating oil } \\
\text { wastewater } \\
\mathrm{C}_{\mathrm{f}}=30 \mathrm{mg} \cdot \mathrm{L}^{-1} \\
\mathrm{C}_{\mathrm{f}}=100 \mathrm{mg} \cdot \mathrm{L}^{-1}\end{array}$ & $\begin{array}{l}55.26 \\
50.00\end{array}$ & $\begin{array}{l}98.00 \\
97.00\end{array}$ & $\begin{array}{c}\text { Silva et al., } \\
2021\end{array}$ \\
\hline $\begin{array}{l}\text { Low-cost } \\
\text { ceramic }\end{array}$ & $\begin{array}{l}\text { uniaxial dry } \\
\text { compaction }\end{array}$ & $\begin{array}{c}2.0 \text { bar } \\
25^{\circ} \mathrm{C}\end{array}$ & $\begin{array}{c}\text { lubricating oil } \\
\text { wastewater } \\
\mathrm{C}_{\mathrm{f}}=235 \mathrm{mg} . \mathrm{L}^{-1}\end{array}$ & 16.53 & 100.00 & $\begin{array}{c}\text { Silva et al., } \\
2021\end{array}$ \\
\hline
\end{tabular}

\section{Source: Authors.}

It was noticed that the low-cost membrane (present work) removed more than composite membranes (Scheibler et al., 2014; Barbosa et al., 2020; Silva et al., 2021). This case be interpreted by different structures, feedstock and conditions of preparation of membrane. In the preparation conditions of the membranes, the preparation method, sintering, design must be taken into account.

\section{Conclusion}

After studying the properties of the bofe clay from Paraíba, Brazil, the preparation of a low-cost ceramic membrane was successful.

A XRD technique demonstrated that the bofe clay is formed by clay minerals of the smectite group, possessing quartz as an impurity.

The low-cost membrane was prepared using the uniaxial dry compaction method and the reduction in peak intensity and the presence of expected characteristic peaks due to the composition of the material and its sintering conditions was evidenced. 
In this study, the removal of mineral lubricating oil using the low-cost membrane was evaluated, and it was concluded that the membrane has the ability to remove the lubricating oil, showing its high efficiency, with a rejection coefficient of $100.00 \%$, due to characteristic such as porosity $(48.16 \%)$.

When comparing the two systems, batch and membrane separation, it is concluded that the performance of the low-cost membrane was superior to the system using organophilic clay.

The present study represents the development of suitable strategies to prepare low-cost ceramic membranes and organoclays used in oil/water separation, as well as future applications in dye removal.

\section{Acknowledgements}

The authors gratefully acknowledge Petrobras, CAPES (Coordenação de Aperfeiçoamento de Pessoal de Nível Superior), CNPq (Conselho Nacional de Pesquisa e Desenvolvimento) and FAPESQ (Fundação de Apoio a Pesquisa do Estado da Paraíba) for the financial support.

\section{References}

Abuhasel, K., Kchaou, M., Alquraish, M., Munusamy, Y. \& Jeng, Y. T. (2021). Oily Wastewater Treatment: Overview of Conventional and Modern Methods, Challenges, and Future Opportunities. Water, 3, 980. https://doi.org/10.3390/w13070980

Almeida F.A., Botelho E.C., Melo F.C.L., Campos T.M.B., \& Thim G.P. (2009). Influence of cassava starch content and sintering temperature on the alumina consolidation technique. Journal of European Ceramic Society, 29, 1587-1594. https://doi.org/10.1016/j.jeurceramsoc.2008.10.006

Alzahrani, S., Mohammad, A.W. (2014). Challenges and trends in membrane technology implementation for produced water treatment: A review. Journal of Water Process Engineering, 4, 107-133. http://dx.doi.org/10.1016/j.jwpe.2014.09.007

Araújo, A. P. (2010). 80p. Síntese de membranas zeolíticas (Y/membrana cerâmica) visando sua aplicação na catálise. Dissertação (Mestrado em Engenharia Química), Universidade Federal de Campina Grande, Campina Grande, Paraíba.

Araújo, A. P. (2014). 110p. Avaliação da influência dos parâmetros de síntese na preparação de membranas zeoliticas Y/a-alumina. Tese (Doutorado em Engenharia Química), Universidade Federal de Campina Grande, Campina Grande, Paraíba.

Araújo, A. P., \& Rodrigues, M. G. F. (2012). Síntesis de una membrana zeolítica de tipo y soportada en $\alpha$-alúmina: efecto del tratamiento térmico sobre la estructura. Avances en ciencias e ingeniería, 3, 51-58.

Araújo, A.P., Brito, A. L. F., Cunha, R. S. S., \& Rodrigues, M. G. F. (2014). Efeito de diferentes concentrações de sílica sobre a sintese da membrana zeolítica (Zeólita Y/a-alumina), In Anais do CITEM - IX Ibero-American Congress on Membrane Science and Technology.

Araújo, A. P., Silva, V. J., Crispim, A. C., Menezes, R. R., \& Rodrigues, M. G. F. (2010). Synthesis of Zeolite Membrane (Y/a-Alumina). Materials Science Forum, 660-661, 1058-1063. http://doi.org/10.4028/www.scientific.net/MSF.660-661.1058

Barbosa A.S., Barbosa AS, \& Rodrigues, M. G. F. (2019). Influence of the methodology on the formation of zeolite membranes MCM-22 for the oil/water emulsion separation. Cerâmica. 65, 531-540. http://dx.doi.org/10.1590/0366-69132019653762676

Barbosa, A. S., Barbosa, A. S., \& Rodrigues, M. G. F. (2019). Influence of the methodology on the formation of zeolite membranes MCM-22 for the oil/water emulsion separation. Ceramica, 65(376), 531-540. https://doi.org/10.1590/0366-69132019653762676

Barbosa, A.S. (2009). 98p. Síntese de membranas zeolíticas (MCM-22/membrana cerâmica), em escala de laboratório, utilizando o método de síntese hidrotérmica. Dissertação (Mestrado em Engenharia Química), Universidade Federal de Campina Grande, Campina Grande, Paraíba.

Barbosa, A.S. (2013). 107p. Preparação de membranas zeolíticas (MCM-22/ -alumina), em escala de laboratório, utilizando rubbing, dip-coating e transporte a vapor. Tese (Doutorado em Engenharia Química), Universidade Federal de Campina Grande, Campina Grande, Paraíba.

Barbosa, A.S., (2015). 158p. Preparação de membranas zeolíticas (Y/gama-alumina) utilizando diferentes métodos e sua avaliação no processo de separação emulsão óleo/água. Tese (Doutorado em Engenharia Química), Universidade Federal de Campina Grande, Campina Grande, Paraíba.

Barbosa, A.S., Barbosa, A.S., \& Rodrigues, M.G.F. (2018). Contaminants Removal in Wastewater Using Membrane Adsorbents Zeolite Y/Alpha-Alumina. Materials Science Forum, 912, 12-15. http://doi.org/10.4028/www.scientific.net/MSF.912.12

Barbosa, A.S., Barbosa, A.S., \& Rodrigues, M.G.F. (2019). Y-Type Zeolite Membranes: Synthesis by Secondary by Method and Application in Treatment of Oily Effluents. Materials Science Forum, 958, 23-28. https://doi.org/10.4028/www.scientific.net/MSF.958.23

Barbosa, A.S., Barbosa, A.S., \& Rodrigues, M.G.F. (2021). Study of the influence of the aluminum source (acetate or sulfate) on the synthesis of the ceramic membrane and applications of emulsion oil water: use and reuse. Research, Society and Development, 10, e75101321023.

Barbosa, A.S., Barbosa, A.S., \& Rodrigues, M. G. F. (2015). Synthesis of MCM-22 zeolite membrane on a porous alumina support. Materials Science Forum, 805, 272-278. https://doi.org/10.4028/www.scientific.net/MSF.805.272 
Barbosa, A.S., Barbosa, A.S., Barbosa, T. L. A., \& Rodrigues, M. G. F. (2018). Synthesis of zeolite membrane (NaY/alumina): Effect of precursor of ceramic support and its application in the process of oil-water separation. Separation and Purification Technology, 200, 141-154. https://doi.org/10.1016/j.seppur.2018.02.001

Barbosa, A.S., Barbosa, A.S., \& Rodrigues, M. G. F. (2015). Synthesis of zeolite membrane (MCM-22/ $\alpha$-alumina) and its application in the process of oilwater separation. Desalination and Water Treatment, 56(13), 3665-3672. https://doi.org/10.1080/19443994.2014.995719

Barbosa, T. L. A., Silva, F. M. N., Barbosa, A. S., Lima, E. G., \& Rodrigues, M. G. F., (2020). Synthesis and application of a composite NaA zeolite/gammaalumina membrane for oil-water separation process. Cerâmica, 66, 137-144.

Barredo-Damas S., Alcaina-Miranda M.I., Bes-Piá A., Iborra-Clar M.I., IborraClar A., \& Mendoza-Roca J.A. (2010). Ceramic membrane behavior in textile wastewater ultrafiltration. Desalination, 250, 623-628. https://doi.org/10.1016/j.desal.2009.09.037

Bergaya, F., Theng, B.K.G, \& Lagaly, G. (2006). Handbook of Clay Science.

Burggraaf, A.J., Cot, L. (1996). Fundamentals of inorganic membrane science and technology.

Chandradass J., Ki H.K., Dong Sik B., Prasad K., Balachandar G., Athisaya Divya S., et al. (2009). Starch consolidation of alumina: Fabrication and mechanical properties. Journal of the European Ceramic Society, 29, 2219-2224. https://doi.org/10.1016/j.jeurceramsoc.2009.02.001

Cot, L., Ayral, A., Durand, J., Guizard, C., Hovnanian, N., Julbe, A., Larbot, A. (2000). Inorganic membranes and solid state sciences. Solid State Sciences, 2 , 313-334. https://doi.org/10.1016/S1293-2558(00)00141-2

Cunha, R. S. S. (2017). 149p. Preparação e caracterização de membranas compósitas tubulares aplicadas a separação emulsão óleo/água. Tese (Doutorado em Engenharia Química), Universidade Federal de Campina Grande, Campina Grande, Paraíba.

Ebrahimi, M., Kerker, S., Schmitz, O., Schmidt, A.A., \& Czermak, P. (2017). Evaluation of the Fouling Potential of Ceramic Membrane Configurations Designed for the Treatment of Oilfield Produced Water. Separation Science and Technology, 53, 349-363. https://doi.org/10.1080/01496395.2017.1386217

Ferrage, E. (2016). Investigation of the interlayer organization of water and ions in smectite from the combined use of diffraction experiments and molecular simulations. A review of methodology, applications, and perpectives. Clays and Clay Minerals, 64, 346-71. http://doi.org/10.1346/CCMN.2016.0640401

Ghouil, B., Harabi, A., Bouzerara, F., Brihi, N. (2016). Elaboration and characterization of ceramic membrane supports from raw materials used in microfiltration, Desalination and Water Treatment, 57, 5241-5245. https://doi: 10.1080/19443994.2015.1021098

Gupta, R. K., Dunderdale, G. J., England, M. W. \& Hozumi, A. (2017). Oil/water separation techniques: a review of recent progresses and future directions. Journal of Materials Chemistry, 5, 16025-16058.

Hazlett, R.N. (1969). Fibrous bed coalescence of water-steps in coalescence process. Industrial \& Engineering Chemistry Fundamentals, 8, $625-632$.

He, Z., Lyu, Z., Gu, Q., Zhang, L., Wang, J. (2019). Ceramic-based membranes for water and wastewater treatment. Colloids and Surfaces A Physicochemical and Engineering Aspects, 578, 123513. https://doi.org/10.1016/j.colsurfa.2019.05.074

Hsieh H.P. (1996). Inorganic membranes for separation and reaction.

Kaur H., Bulasara V.K., Gupta R.K. (2016). Preparation of kaolin-based low-cost porous ceramic supports using different amounts of carbonates. Desalination and Water Treatment, 57, 15154-15163. https://doi.org/10.1080/19443994.2015.1068226

Kaur H., Kumar V., Raj B., Gupta K. (2016). Effect of carbonates composition on the permeation characteristics of low-cost ceramic membrane supports. Journal of Industrial and Engineering Chemistry, 44, 185-194. https://doi.org/10.1016/j.jiec.2016.08.026

Le, T.V., Imai, T., Higuchi, T., Yamamoto, K., Sekine, M., Doi, R., Vo, H.T., Wei, J. (2013). Performance of tiny microbubbles enhanced with "normal cyclone bubbles" in separation of fine oil-in-water emulsions. Chemical Engineering Science, 94, 1-6. https://doi.org/10.1016/j.ces.2013.02.044

Lorente-Ayza M.-M., Sánchez E., Sanz V., \& Mestre S. (2015). Influence of starch content on the properties of low-cost microfiltration ceramic membranes. Ceramics International, 41, 13064-13073. https://doi.org/10.1016/j.ceramint.2015.07.092

Matsuno, A., Junaid, Z. M., Saito, T., Thi, H., Dang, T., Huyen, P. T., Nga, T. T. V. \& Kawamoto, K. (2021). Oil/Water separation techniques using hydrophobized/oleophilized grains: a review of recent studies. International Journal of GEOMATE, 20, 28-34.

Mercurio, M., Sarkar, B., \& Langella, A. (2018). Modified Clay and Zeolite Nanocomposite Materials. Environmental and Pharmaceutical Applications.

Mestre, S., Gozalbo, A., Lorente-Ayza, M. M., \& Sánchez, E. (2019). Low-cost ceramic membranes: A research opportunity for industrial application, Journal of the European Ceramic Society, 39, 3392-3407. https://doi.org/10.1016/j.jeurceramsoc.2019.03.054

Monash, V., \& Pugazhenthi, G. (2011). Development of Ceramic Supports Derived from Low-Cost Raw Materials Membrane Applications and its Optimization Based on Sintering Temperature. International Journal of Applied Ceramic Technology, 8, 227-238. https://doi.org/10.1111/j.17447402.2009.02443.x

Mota M. F., Silva J. A., Queiroz M. B., Laborde H. M., \& Rodrigues M. G. F. (2011). Organophilic clay for oil/water separation process by finite bath tests. Brazilian Journal of Petroleum and Gas, 5, 97-107. http://doi.org/10.5419/bjpg2011-0011.

Mota, J. D. (2017). 145p. Preparação de membranas tubulares compósitas e sua avaliação na separação de emulsão óleo/água: utilização e reutilização. Tese (Doutorado em Engenharia Química), Universidade Federal de Campina Grande, Campina Grande, Paraíba.

Mota, Mariaugusta Ferreira, Machado, F., \& Rodrigues, M. G. F. (2012). Influence of exchanged surfactant on the structure and adsorption properties of 
brazilian green mud clay. Materials Science Forum, 727-728, 1473-1478. https://doi.org/10.4028/www.scientific.net/MSF.727-728.1473

Nandi, B.K., Uppaluri, R., \& Purkait, M. K. (2008). Preparation and characterization of low cost ceramic membranes for micro-filtration applications, Applied Clay Science, 42, 102-110. https://doi.org/10.1016/j.clay.2007.12.001

Oliveira, G.C., Mota M.F., Silva, M.M., Rodrigues, M.G.F., \& Laborde, H.M. (2012). Performance of natural sodium Clay treated with ammonium salt in the separation of emulsified oil in water. Brazilian Journal of Petroleum and Gas, 6, 171-183. http://doi.org/10.5419/bjpg2012-0014.

Padaki, M., Surya Murali, R., Abdullah, M. S., Misdan, N., Moslehyani, A., Kassima, M. A., Hilal, N., Ismail, A. F. (2015). Membrane technology enhancement in oil-water separation. A review. Desalination, 357, 2015, 197-207.

Pereira, K. R. O., Hanna, R. A., Ramos Vianna, M. M. G., Pinto, C. A., Rodrigues, M. G. F., \& Valenzuela-Diaz, F. R. (2005). Brazilian organoclays as nanostructured sorbents of petroleum-derived hydrocarbons. Materials Research, 8(1), 77-80. https://doi.org/10.1590/s1516-14392005000100014

Queiroz, M. B. (2010). 92p. Síntese de zeólita ZSM-5 e membranas zeolíticas (ZSM-5/ -alumina) através do método hidrotérmico. Dissertação (Mestrado em Engenharia Química), Universidade Federal de Campina Grande, Campina Grande, Paraíba.

Rezende, M. J., \& Pinto A. C. (2016). Esterification of fatty acids using acidactivated Brazilian smectite natural clay as a catalyst. Renewable Energy, 92, 171-7. http://doi.org/10.1016/j.renene.2016.02.004

Rodrigues M. G. F. (2003). Physical and catalytic characterization of smectites from Boa-Vista, Paraíba, Brazil. Cerâmica, 49, 146-150. https://doi.org/10.1590/S0366-69132003000300007

Rodrigues, S. C. G., Queiroz, M.B., Pereira, K.R.O., Rodrigues, M.G.F., \& Valenzuela-Diaz, F.R. (2010) Comparative Study of Organophilic Clays to be Used in the Gas \& Petrol Industry. Materials Science Forum, 660, 1037-1042.

Santos, E. R. F., 2014. 127p. Síntese das membranas inorgânicas (ZSM-5/gama-alumina, MCM-41/gama-alumina e compósito MFI-MCM-41/gama-alumina) destinadas separação emulsão óleo/água. Dissertação (Mestrado em Engenharia Química), Universidade Federal de Campina Grande. Campina Grande, Paraíba.

Santos, E. R. F., Mota, M. F., Sousa, A. K. F., Silva, M. M., Rodrigues, M. G. F., \& Lau, L. Y. (2014). Influência do tipo de semente na síntese da membrana zeolítica ZSM-5/ $\alpha$-alumina, In Anais do CITEM - IX Ibero-American Congress on Membrane Science and Technology.

Santos, E. R. F., Silva, F. M. N., Barbosa, T. L. A., \& Rodrigues, M. G. F., (2015). Synthesis and characterization of zeolite membrane Composite MFI/MCM41, In Anais do 12 International Conference on Catalysis in Membrane Reactors ICCMR12.

Santos, E. R. F., Silva, M. M., Rodrigues, M. G. F., \& Lau, L. Y. (2014). Study of two methods in the preparation of zeolite membrane (ZSM-5/alfa-alumina): Rubbing and dip-coating, In Anais do CITEM - IX Ibero-American Congress on Membrane Science and Technology.

Scheibler, J. R., Santos, E. R. F., Barbosa, A. S., \& Rodrigues, M. G. F. (2015). Performance of zeolite membrane (ZSM-5/ $\gamma$-Alumina) in the oil/water separation process. Desalination and Water Treatment, 56(13), 3561-3567. https://doi.org/10.1080/19443994.2014.986536

Scheibler, J. R. (2015). Síntese de membranas zeolíticas (ZSM-5/g-alumina, ZSM-5/a-alumina) por pore-plugging para permeação de N2. Dissertação (Mestrado em Engenharia Química), Universidade Federal de Campina Grande. Campina Grande, Paraíba.

Silva, E. L., Patrício, A. C. L., Oliveira, G. C., \& Rodrigues, M. G. F. (2014) Evaluation of a Sodic Organoclay as Adsorbent for Removing Oil/Water in a Synthetic Wastewater. Materials Science Forum, 798-799: 127-132. http://doi/10.4028/www.scientific.net/MSF.798-799.127

Silva, F. M. N. (2017). 184p. Síntese de membranas zeolíticas (Mordenita/a-alumina) utilizando os métodos de síntese hidrotérmica, dip-coating e transporte em fase vapor e avaliação na separação emulsão óleolágua. Tese (Doutorado em Engenharia Química), Universidade Federal de Campina Grande, Campina Grande, Paraíba.

Silva, F. M. N., Barbosa, T. L. A., \& Rodrigues, M. G. F. (2015). Synthesis and characterization of zeolite membrane MOR dip coating method. In 12 th Internacional Conference on Catalysis in Membrane Reactors.

Silva, F.M.N., Bezerra Junior, A. C., Barbosa, T. L. A., \& Rodrigues, M. G. F. (2015). Single gas permeation in ZSM-5 zeolite membrane. In Euromembrane.

Silva, F. M. N., Lima, E. G., Barbosa, T. L. A., \& Rodrigues, M.G.F. (2017). Development of MOR Zeolite Membranes Supported nn X-alumina and $\alpha$ alumina obtained from the decomposition of aluminum sulphate. In 13th Internacional Conference on Catalysis in Membrane Reactors.

Silva, F. M. N.; \& Rodrigues, M. G. F. (2015). Preparation and characterization of mordenite inorganic membrane for gas separation. In: Euromembrane.

Silva, L. R. B., Barbosa, T. L. A., \& Rodrigues, M. G. F. (2021). Membrana zeolítica NaA : Preparação e aplicação para tratamento de emulsão óleo/água. In Anais do IV CONEPETRO E VI WEPETRO.

Silva, L. R. B., Silva, F. A. S., Barbosa, T.L.A., \& Rodrigues, M.G.F. (2021). Membrana cerâmica de baixo custo para tratamento de efluentes oleosos. Research, Society and Development, 10, e253101321071.

Souza Santos, P. (1989). Ciências e Tecnologia de Argilas.

Standard Methods of Testing Sorbent Performance of Adsorbents - Designation: ASTM F726 -99.

Standard Methods of Testing Sorbent Performance of Adsorbents - Designation: ASTM F716 -82 (Reapproved 1993).

Standard Test Methods for Apparent Porosity, Water absorption, Apparent Specific Gravity, and Bulky Density of Burned Refractory Brick and Shapes by Boiling Water - Designation: ASTM C 20 (2000). 
Research, Society and Development, v. 10, n. 15, e215101522542, 2021

(CC BY 4.0) | ISSN 2525-3409 | DOI: http://dx.doi.org/10.33448/rsd-v10i15.22542

Sutherl, K. Filters and Filtration Handbook, 5th ed.; Butterworth-Heinemann: Oxford, UK, 2008.

Tummons, E., Han, Q., Tanudjaja, H. J., Hejase, C. A., Chew, J. W., Tarabara, V. V. (2020). Membrane fouling by emulsified oil: A review. Separation and Purification Technology, 248, 116919. https://doi.org/10.1016/j.seppur.2020.116919

Vasanth, D., Uppaluri, R., \& Pugazhenthi, G. (2011). Influence of sintering temperature on the properties of porous ceramic support prepared by uniaxial dry compaction method using low-cost raw materials for membrane applications. Separation Science and Technology, 46(8), 1241-1249. https://doi.org/10.1080/01496395.2011.556097

Xi, Y., Mallavarapu, M., \& Naidu, R. (2010) Preparation, characterization of surfactants modified Clay minerals and nitrate adsorption. Applied Clay Science, 48, 92-96. https://doi.org/10.1016/j.clay.2009.11.047

Yang G. C. C., \& Tsai C. M. (2008). Effects of starch addition on characteristics of tubular porous ceramic membranes substrates. Desalination, 233, 129-136. https://doi.org/10.1016/j.desal.2007.09.035

Zhu, Y., Wang, D., Jiang, L., Jin, J. (2014). Recent progress in developing advanced membranes for emulsified oil/water separation. NPG Asia Materials (2014) 6, e101. doi:10.1038/am.2014.23 